\title{
NOVAS PROPRIEDADES E SUA FUNCIONALIZAÇÃO: A INTERSECÇÃO ENTRE OS DIREITOS CULTURAIS E DOS DIREITOS DE AUTOR NA ATUAL REALIDADE BRASILEIRA
}

\author{
NEW PROPERTIES AND THEIR FUNCTIONS: THE RELATIONSHIP BETWEEN THE \\ CULTURAL RIGHTS AND THE AUTHOR'S RIGHTS IN THE PRESENT BRAZILIAN \\ REALITY
}

\author{
Carolina Geissler Miranda de Barros ${ }^{1}$ \\ Leonardo da Silva Sant'Anna² \\ José Carlos Vaz e Dias ${ }^{3}$
}

\begin{abstract}
RESUMO: Este trabalho realiza uma análise sobre a proteção de direitos autorais e sua interseção com direitos culturais no Brasil, tendo em vista a revolução tecnológica e mudanças no consumo de produtos do entretenimento, como músicas, filmes e livros. Procura desenvolver também uma crítica sobre a dicotomia entre acesso extensivo à cultura e a proteção proprietária dos bens intelectuais, bem como o surgimento de um novo direito autoral. Mais ainda, o presente artigo procura identificar qual seria o papel de novos modelos de negócio digital nesse contexto de desafios inspirados, principalmente, pela digitalização das relações jurídicas e influência tecnológica. A metodologia utilizada foi a hipotética-dedutiva, instrumentalizada pela pesquisa qualitativa e pela documentação indireta. Conclui-se pela necessidade de mais do que apenas a alteração legislativa, sendo indispensável um acerto dos comportamentos dos usuários e dos detentores de produtos intelectuais no acesso e respeito às criações.
\end{abstract}

PALAVRAS-CHAVE: Direito do Autor. Direitos Culturais. Funcionalização dos Direitos de Propriedade. Digitalização das Relações Jurídicas.

\footnotetext{
${ }^{1}$ Advogada. Mestranda em Direito da Empresa e Atividades Econômicas pela Universidade do Estado do Rio de Janeiro ("UERJ"). Bacharel em Direito pela Universidade Federal do Rio de Janeiro ("UFRJ").

${ }^{2}$ Professor Adjunto em Direito Comercial pela Faculdade de Direito da UERJ. Doutor em Ciências pela Escola Nacional de Saúde Pública Sérgio Arouca ("ENSP”) da Fundação Oswaldo Cruz ("FIOCRUZ")

${ }^{3}$ Professor Adjunto em Direito da Propriedade Intelectual e Direito Comercial pela Faculdade de Direito da UERJ e sócio do escritório Vaz e Dias Advogados \& Associados. Mestre e Doutor em Direito da Propriedade Intelectual e Investimento Estrangeiro pela Universidade de Kent Inglaterra
}

- Artigo convidado 
ABSTRACT: This work intends to produce an analysis on the protection of copyright and its intersection with cultural rights in Brazil in view of the technological revolution and changes in the consumption of entertainment products such as music, movies and books. It also intends to develop a critical view of the dichotomy between the extensive access to culture and the proprietary protection of the intellectual matters as well as the development of a new copyright rights. More importantly, the present article aims to identify the effectives roles of the new models of digital business in the context of challenges based on the digitization of legal relationships. The methodology used for the production of this article was the hypothetical-deductive one, instrumented by qualitative research and indirect documentation. It is possible to conclude that more than a legislative alteration.is needed, becoming indispensable thereby the concert between the end-use behaviors and the titleholders of intellectual products as to the access and creation respect.

KEYWORDS: Author's Rights. Cultural Rights. Property Function. Digitization of Legal Relations.

\section{INTRODUÇÃO}

O presente trabalho aborda, sob a luz da legislação vigente e de artigos sobre temáticas conexas, as dificuldades impostas ao direito autoral pela expansão brusca da digitalização e do uso dos meios digitais utilizados pelas pessoas para o acesso às obras intelectuais, tais como textos literários, obras artísticas, cientificas e também os programas de computador.

Procura-se demonstrar os maiores desafios encontrados pelas indústrias criativas para a devida adaptação à nova realidade imposta pela internet, além daquelas determinadas pela funcionalização do direito autoral e ascensão dos direitos culturais e solidariedade humana.

Há tempos que a utilização de mídias digitais e da internet, a cada dia mais frequente e presente nas relações contemporâneas, vem causando comoção no campo jurídico. Uma das recentes discussões e controvérsias envolvendo a possível inadequação da proteção às obras intelectuais pelo direito autoral refere-se à inteligência artificial. Em artigo recentemente publicado por BOND (2017) na revista IP WATCHDOG, abordou-se como a Inteligência Artificial através da criação de 'supercomputadores' e robôs estão interferindo e/ou implementando modificações substanciais nos modelos de negócio, bem como na forma como o direito da propriedade intelectual protege as criações. Ressalta-se aqui que as possíveis "criações” são realizadas por "máquinas” e não por seres humanos. Seriam essas "criações" propriedade do computador? Quais seriam 
implicações proprietárias para esses desenvolvimentos? Como gerenciar essas novas propriedades? Quem são os proprietários dessas novas obras? Esses alguns questionamentos enfrentados atualmente pelo direito autoral.

O referido artigo traz à tona novamente as dificuldades do direito autoral em comportar e incluir as tecnologias digitais e, neste momento, deve-se ressaltar que as primeiras dificuldades surgem do fato de que o ordenamento jurídico existente opera, via de regra, sobre coisas materiais e bens jurídicos imateriais expressos necessariamente por meio físico ou fixadas em suporte normalmente tangíveis. Esse é o caso dos textos literários, fotografias e músicas, que são obras intelectuais e intangíveis (não podem ser tocadas), observáveis visualmente e pela audição, mas que sempre foram concebidas pelas pessoas por meio da aquisição de livros, discos, fitas e CDs.

O mundo digital, como sabemos, é essencialmente imaterial e sem suporte tangível ou físico, composto por uma grande sequência de números e códigos-fonte que a maioria das pessoas não compreende por completo.

A digitalização, ou digitization, trouxe consigo uma nova forma para os possíveis relacionamentos entre sujeitos de direito, novas formas de contratação, e, até mesmo, novas hipóteses de cometimento de crimes, novidades que atingiram, inclusive e principalmente, o direito autoral advindo das indústrias criativas. Os ramos da música, das obras literárias e até mesmo das obras artísticas e cinematográficas sofrem com a incapacidade da lei autoral de controlar o fluxo desautorizado de informação e a troca de dados pela internet. A fiscalização para buscar o respeito aos direitos destes artistas e/ou dos criadores das obras intelectuais se torna cada vez mais difícil, mesmo com os mecanismos de gestão coletiva implantados pela lei autoral, que ainda não identificaram uma forma ideal de arrecadação e acompanhamento do fluxo de material autoral pela internet.

No entanto, a Era da internet e as novas tecnologias como a inteligência artificial não evidenciam somente más experiências. As novas tecnologias fizeram surgir novos processos de mercantilização do material autoral sem que fosse necessário restringir o conteúdo. Novos modelos de negócio e monetização de trabalho artísticos surgem todos os dias no espaço virtual do worldwide web, redemocratizando um mercado que antes dependia totalmente das grandes gravadoras, editoras e outras empresários gerenciadores de conteúdo artístico.

Somada a este cenário de democratização dos meios de comunicação, via inserção de novas 
tecnologias, está a ascensão do conceito de acesso e utilização abrangente de obras autorais por terceiros, sem que haja necessariamente a prévia e expressa autorização de seus titulares. Com o empoderamento do público consumidor das obras intelectuais protegidas pelo direito autoral e a expansão da constitucionalização do direito privado, o acesso abrangente dessas obras passou a ser classificado como uma expressão da funcionalização dos direitos autorais, exigida para qualquer propriedade privada, e passou a ter um papel central na disseminação e promoção da Cultura e da Educação.

Salienta-se aqui que a promoção á Cultura e Educação é fundamentação para a concretização das aspirações constitucionais, baseadas nos princípios da solidariedade social e afirmação da dignidade humana, que se encontram preconizados essencialmente nos incisos III do artigo $1^{\circ}$. e inciso I e III do art. $3^{\circ}$. e item V do art. 23 da Constituição Federal de 1988.

O presente artigo é fruto de pesquisa qualitativa de cunho teórico cujo objetivo é confirmar a premissa de que deve-se construir um novo direito autoral brasileiro, que possa promover o acesso abrangente à cultura aos cidadãos brasileiros, dinamizar a cultura nos territórios brasileiros e estrangeiros, através da internet e plataformas online de comunicação entre pessoas e divulgação de informações como a internet.

Optou-se pela aplicação de análise de conteúdo, através do estudo de textos teóricos e textos legais, bem como de matérias jornalísticas sobre o tema. A técnica de pesquisa escolhida foi a da documentação indireta, ou seja, a revisão de literatura através de pesquisa bibliográfica e documental sobre a proteção de direitos culturais e autorais e sua interseção.

Na primeira parte será feita uma análise dos pontos mais frágeis da legislação brasileira de direito autorais. O que poderia e o que se pretende alterar na lei atual, pelo poder legislativo, que poderia de alguma forma aproximar a sua eficácia ao atendimento dos princípios constitucionais da dignidade humana, solidariedade social e amplo acesso à cultura, inclusive mencionando as alterações já perpetradas no ramo da gestão coletiva de direitos.

Em um segundo momento serão abordados os problemas reais impostos pela globalização, a expansão do acesso à informação, a internet e a digitalização das obras autorais e os desafios apresentados aos diferentes nichos da indústria. Serão apontados os novos modelos de negócios digitais que vêm alterando a forma de monetização da produção autoral e, ainda, uma avaliação de novas formas de se enxergar estes direitos. 
$\mathrm{Na}$ terceira seção pretende-se apresentar os principais aspectos envolvendo os direitos culturais, de que tipos de direitos são compostos e sua importância para a construção de uma sociedade justa e igualitária. Serão abordados pontos relacionados ao direito de acesso à informação e à cultura e os diferentes aspectos culturais que devem ser protegidos.

Será evidenciado neste trabalho a necessidade de alterações nas leis de direitos autoral, bem como da forma como o direito autoral deve ser compreendido em vista das necessidades de valorização dos direitos culturais, que pode ser compreendido como uma maneira de expressão da função social da propriedade, e da nova forma de propagação de conteúdo autorais, através das plataformas digitais.

1 Expectativas de Alteração legislativa da Lei de Direitos Autorais

Constitui princípio básico da doutrina jurídica que tudo aquilo que possui valor para os seres humanos e é patrimonialmente apreciável merece uma proteção pelo direito. O objetivo primário é garantir ao seu titular a possibilidade de exploração extensiva dentro de limites da coisa ou do bem jurídico em si. Essa regra aplica-se a todos e quaisquer bens, sejam eles produtos, serviços, animais, plantas, créditos, nome de pessoa, voz e imagem. A justificativa básica para essa proteção decorre do entendimento, segundo o qual se uma pessoa é proprietária de um bem (coisa, por exemplo), fica garantido a esta pessoa o direito de uso e exploração direta, bem como a autorização para terceiros, desde que seja exercido dentro dos limites permitidos pelo direito e sem desrespeitar direitos de terceiros e da coletividade.

Esses bens são denominados "bens jurídicos" e recebem proteção peculiar relacionadas às suas qualidades físicas ou jurídicas (mobilidade ou imobilidade, infungibilidade ou fungibilidade) e à maneira de relacionar com o seu titular (BRASIL, Código Civil, 2002, arts. 79 a 103). Quando estiverem atrelados ao intimo humano, a proteção será baseada nos direitos da personalidade, sendo incidentes as regras de integridade física, dentre outras com repercussões diretas nos seres humanos.

Quando decorrerem necessariamente da relação objeto e dono com a exploração pecuniária (e forem passíveis de agregação ao patrimônio), compreende-se que os bens jurídicos 
passam a ser regulados pelos direitos da propriedade, conforme artigos 1.228 do Código Civil (BRASIL, 2002). ${ }^{4}$

Estão inseridos como direitos de propriedade o resultado da criação intelectual, expressa em meio físico tangível (que pode ser tocado ou sentido pelos seres humanos), na forma literária, artística ou científica. Estão sob a tutela de direito autoral os livros, as pinturas, os programas de computador, as músicas, películas cinematográficas, dentre outros que decorram da expressão humana.

A Lei Federal $n^{\circ} 9.610 / 1988$ é a peça legislativa principal que aborda a proteção e a exploração das obras intelectuais protegidas pelo Direito Autoral, que possuem uma natureza eminentemente estética e excludente da utilidade. ${ }^{5} \mathrm{~A}$ forma de proteção legal das criações estéticas no Brasil insere-se no "regime do direito do autor", que foi criado na Europa continental a partir do século XVIII e influenciou a Convenção Internacional de Berna ${ }^{6}$, de 9 de setembro de 1886, da qual o Brasil é país signatário.

Isso significa que a regulação de direito autoral se encontra inspirada no modelo francês de

4 Art. 1.228 do Código Civil: "Direito real por excelência, direito subjetivo padrão, ou "direito fundamental" (Pugliatti. Natoli, Planiol, Ripert e Boulanger), a propriedade mais se sente do que se define, à luz dos critérios informativos da civilização romano-cristã. A ideia de "meu e teu", a noção do assenhoreamento de bens corpóreos e incorpóreos independe do grau de cumprimento ou do desenvolvimento intelectual. Não é apenas o homem do direito ou o buiness man que a percebe. Os menos cultivados, os espíritos rudes, e até crianças tem dela a noção inata, defendem a relação jurídica dominial, resistem ao desapossamento, combatem o ladrão. Todos "sentem" o fenômeno da propriedade.

Em termos de generalização, Lafayette atribuiu-lhe o sentido abrangente de todos os direitos que formam o patrimônio, ou todos os direitos que se traduzem numa expressão pecuniária. E Serpa Lopes declara, peremptoriamente, estar construída a teoria dos direitos reais em torno da propriedade erigida assim em centro de irradiação" (PEREIRA, 2004, pg 89).

5 O sistema normativo dos direitos autorais está essencialmente disposto na Lei 9.610, de 19 de fevereiro de 1998 (denominada "Lei de Direitos Autorais") e na Lei 9.609, de 19 de fevereiro de 1998 ("Lei de Software"). Os direitos autorais estão tutelados por duas convenções internacionais, quais sejam a Convenção de Berna de 1886 (promulgada pelo Decreto n. 75.699, de 6 de maio de 1975) para a proteção das obras literárias e artísticas e a Convenção Universal sobre Direitos do Autor de 1971 (promulgada pelo Decreto n. 76.905, de 24 de dezembro de 1975).

Deve-se mencionar também a relevância da Lei de Software (Lei n ${ }^{\circ}$. 9.609, de 18 de fevereiro de 1998), que possui uma conotação de proteção atrelada ao direito autora e o Código Civil Brasileiro (Lei no. 10.406, de 10 de janeiro de 2002), sendo que esta peça legislativa cuida da matéria de direito autoral de forma complementar, no que tange à prescrição da ação de reclamação de direitos, dentre outros aspectos gerais.

A Convenção de Berna para a Proteção relativa à proteção das obras literárias e artísticas (também denominada Convenção da União de Berna ou Convenção de Berna) é entendida como um tratado internacional adotado por um conjunto de países que consideraram relevantes a adoção de regras uniformes e direitos mínimos para os direitos autorais. Desde 1886, a Convenção da União de Berna sofreu os seguintes ajustes: Paris em 05/05/1896, Berlim em 13/11/1908, Berna em 20/03/1914, Roma em 02/06/1928, Bruxelas em 26/06/1948, Estocolmo em 14/07/1967 e Paris em 24/07/1971. Informações disponíveis em www.pt.wikipedia.org/wiki/Convenção da União de_Berna . Acesso em20 de setembro de 2017. 
droit d'auteur. Esse regime tem como aspecto importante o impulso à criação de obras estéticas ${ }^{7} \mathrm{e}$ a confirmação do direito de propriedade do autor sobre a sua obra. Garante-se também o exercício de um "duplo direito" composto pelos direitos morais, especialmente a reivindicação da paternidade e a conexão direta e permanente do criador com a obra mesmo que haja a sua transferência definitiva ou cessão para terceiros.

Os direitos morais são entendidos como poderes que decorrem da personalidade humana e possuem íntima relação com o psíquico e o emocional do criador da obra. Esses direitos morais têm como característica principal a manutenção do vínculo do criador/autor com a sua obra intelectual mesmo que essa obra seja transferida definitivamente ou cedida para terceiros. Essa vinculação permanente do criador decorre de a obra ser uma emanação do seu espírito humano e expressão única e íntima do autor sobre um acontecimento, momento emocional e fato vivenciado ou vislumbrado pelo autor ou no mundo que ele participa.

O outro direito integrante da proteção autoral expressa-se na patrimonialidade. A lei objetiva assegurar aqui, ao criador e/ou titular da obra, as vantagens econômicas da exploração/divulgação no mercado. Dentro dos direitos de propriedade, ficam asseguradas as seguintes faculdades para o seu dono ou titular: (a) Faculdade Protetiva - Expressa por meio da exclusão de terceiros desautorizados sobre o uso da obra. Somente o autor e seus autorizados podem utilizar a obra no mercado. Essa faculdade é denominada de exclusividade; (b) Faculdade Econômica - Relaciona-se à possibilidade de o autor e/ou titular exercer a obra autoral, que inclui a autorização para terceiro utilizar diretamente a obra no mercado (denominado licenciamento de direitos) ou a transferência definitiva de exploração a terceiro ou condicionada (de cessão definitiva ou temporária de direitos).

Com a determinação desses direitos, todos e quaisquer usos por terceiros deverão preceder à expressa autorização do autor, incluindo a reprodução parcial ou total, utilização em outra obra, edição da obra, adaptação, arranjo musical, tradução para qualquer idioma, execução musical e outras modalidades de exploração comercial.

Não obstante a aproximação do arcabouço jurídico brasileiro à forma de proteção às obras intelectuais pelo sistema francês, este recebeu considerável influência do sistema americano, o Copyright, principalmente com relação a sua faceta comercial.

\footnotetext{
7 As obras ou criações estéticas são denominadas no presente trabalho como as obras literárias, artísticas e
} científicas. 
A intenção da proteção autoral, assim como o restante das proteções de propriedade intelectual, é o estímulo a novas criações. Parte-se do pressuposto de que, uma vez assegurados os direitos sobre a produção intelectual durante um período determinado de tempo ao responsável pela produção criativa, ele e outros sentiram-se encorajados a criar e inovar. A proteção permite, portanto, que o criador explore sua criação por aquele período de tempo sem que outras pessoas - a não ser aquelas autorizadas expressamente ${ }^{8}$ por ele - levem o crédito ou lucrem com os frutos de seu trabalho. No entanto, o aspecto comercial dos direitos autorais tem um diferencial com relação à proteção de patentes, pois a produção autoral, usualmente, é diretamente relacionada à subsistência do autor.

Apesar de ser um marco legislativo importante na matéria, a Lei de Direitos Autorais possui severos problemas, relacionados à dualidade de direitos e à forma absolutista como o direito da propriedade com base nos Direitos Reais é concebido. Dentre eles estão os problemas técnicos relacionados à linguagem e ausência de conceitos fundamentais, bem como aqueles referentes às mudanças de comportamento geradas pela internet.

As discussões sobre alteração da legislação autoral, no entanto, começaram logo após a sua promulgação e muitas já foram as alterações feitas desde 1998, o que acabou provocando certas confusão e imprecisão técnicas.

Uma alteração foi recentemente proposta pelo Ministério da Cultura ${ }^{9}$ que levou a questão para consulta pública via internet. No entanto, devido a mudanças de gestão no Ministério e a evidente turbulência política, o texto foi arquivado temporariamente pela Casa Civil da Presidência da República. Apesar da iniciativa, entre o período de consulta pública e o efetivo envio do projeto para análise do legislativo muitas alterações foram feitas no texto inicialmente proposto.

A partir de 2013 diversas questões conexas se tornaram protagonistas na atuação do Legislativo: com a condenação do Escritório Central de Arrecadação e Distribuição (ECAD) no caso desencadeado pelo Conselho Administrativo de Defesa Econômica (CADE) a respeito de um suposto Cartel entre o Escritório e suas Associações. Em vista da necessidade de uma melhor regulamentação sobre a matéria, foi promulgada a Lei 12.853/13. Além da questão concorrencial,

\footnotetext{
8 Art. 29. Lei 9.610/98. "Depende de autorização prévia e expressa do autor a utilização da obra, por quaisquer modalidades (...)"

9 O texto que foi disponibilizado para Consulta Pública pode ser encontrado no sítio do Ministério da Cultura, no seguinte endereço eletrônico: 〈http://www2.cultura.gov.br/consultadireitoautoral/consulta/>
} 
foi colocada como prioridade em 2014 a votação do Marco Civil da Internet, ${ }^{10}$ questão afeta à matéria dos direitos autorais no meio digital, que foi aprovado em abril do mesmo ano.

Apesar do atraso legislativo de cinco anos para aprovação da proposta de alteração da Lei Autoral, ela ainda tem relevância para o ordenamento jurídico, desde que devidamente adaptada às mudanças já ocorridas durante este tempo, tendo em vista que ela trata da harmonização técnicolegislativa de dispositivos que geram incertezas de interpretação, da inclusão de novos dispositivos sobre questões antes omissas ou abordadas de forma insuficiente pela lei e, principalmente, a adequação do diploma ao processo de constitucionalização do direito, com a valorização de princípios, cláusulas gerais e normas abertas - tornando a legislação autoral compatível com o restante do ordenamento jurídico brasileiro. (WACHOWICZ, 2015, p.17)

Para atender à gritante necessidade funcionalização do direito autoral, também são imperativas inclusões e redefinições das limitações e exceções a proteção do direito autoral no Brasil, como exemplo podemos citar aquelas afetas ao direito de cópia privada, além de relativização das infrações com relação às necessidades de instituições de ensino e bibliotecas, ambas fundamentais para a concretização do direito à cultura e para a proteção e promoção da educação no país.

1.1 As mudanças na gestão coletiva de direitos e o papel do ECAD

Devido as dificuldades de controle e arrecadação dos frutos econômicos dos direitos autorais, a Lei Autoral prevê, acertadamente, a livre associação dos artistas, compositores e demais sujeitos de direito titulares de direitos autorais ou conexos. O artigo 99 da Lei ${ }^{\circ} 9.610 / 98^{11}$, por sua vez, disciplina a arrecadação e distribuição de direitos relativos à execução pública de obras musicais e literomusicais e de fonogramas, determinando que as associações manterão um único escritório central para a arrecadação e distribuição comuns destes direitos. Para cumprir com a determinação legislativa as associações representativas da Indústria Fonográfica compõe a

\footnotetext{
10 O Marco Civil da Internet é o nome corriqueiro e comumente utilizado para designar a Lei $\mathrm{n}^{\mathrm{o}}$. 12.965, de 23 de abril de 2014 que "Estabelece princípios, garantias e deveres para o uso da Internet no Brasil". Disponível em http://www.planalto.gov.br/ccivil 03/_ato2011-2014/2014/lei/112965.htm. Acesso em 02 de outubro de 2017.

11 Art. 99 da Lei 9.610/98. "A arrecadação e distribuição dos direitos relativos à execução pública de obras musicais e literomusicais e de fonogramas será feita por meio das associações de gestão coletiva criadas para este fim por seus titulares, as quais deverão unificar a cobrança em um único escritório central para arrecadação e distribuição, que funcionará como ente arrecadador com personalidade jurídica própria e observará os $\S \S 1^{\circ}$ a 12 do art. 98 e os arts. 98-A, 98-B, 98-C, 99-B, 100, 100-A e 100-B. (Redação dada pela Lei n 12.853, de 2013) "
} 
congregação do ECAD.

Trata-se de uma sociedade civil de natureza privada sem objetivo de lucro, reconhecida pela nomenclatura do Código Civil como associação, instituída por lei (Lei Federal $\mathrm{n}^{\circ}$ 5.988/73) e organizado de forma complementar pela LDA (Lei $\mathrm{n}^{\circ}$ 9.610/98). A função principal do escritório é a centralização da representação dos artistas e titulares de direitos conexos. Um dos principais pontos de controvérsia sobre a atuação do Escritório Central é a exclusividade exercida em território nacional para a gestão dos direitos relacionados à execução pública (ARENHART, 2011, p.2).

Apesar de a atuação do ECAD embasar-se nos parâmetros legais especificados nas exigências do artigo $68, \S 2^{\circ}$ da LDA, ${ }^{12}$ sua atuação suscitava diversas controvérsias, principalmente com relação à ausência de transparência e a falta de fiscalização estatal sobre suas atividades. A gestão do ECAD, inclusive, foi objeto de investigação pelo Conselho Administrativo de Defesa Econômica (CADE) por possível formação de cartel $^{13}$, e de uma Comissão Parlamentar de Inquérito (CPI) no Congresso Nacional o que corroborou a incerteza e a insegurança acerca de seu papel. $^{14}$

Tanta insegurança acerca de um gestor importante para o mercado do entretenimento incentivou à intervenção legislativa em 2013, com a edição da Lei 12.853, que engloba algumas das propostas contidas no projeto de alteração da Lei Autoral ${ }^{15}$ A capacidade de autogestão e autorregulamentação que era exercida pelo ECAD antes da modificação proposta em 2013 trazia insegurança e incertezas sobre a regulação deste mercado e o papel do Poder Público, ${ }^{16}$ o que é

12 Art. 68. da Lei 9.610/98. "Sem prévia e expressa autorização do autor ou titular, não poderão ser utilizadas obras teatrais, composições musicais ou lítero-musicais e fonogramas, em representações e execuções públicas.

$\S 2^{\circ}$ Considera-se execução pública a utilização de composições musicais ou lítero-musicais, mediante a participação de artistas, remunerados ou não, ou a utilização de fonogramas e obras audiovisuais, em locais de freqüência coletiva, por quaisquer processos, inclusive a radiodifusão ou transmissão por qualquer modalidade, e a exibição cinematográfica."

13 Conforme divulgado pelo próprio Ecad em um comunicado aos titulares que pode ser acessado no sítio: <http://www.ecad.org.br/pt/eu-faco-musica/comunicados-aostitulares/Documents/Comunicado\%20aos\%20Titulares\%20Decis\%C3\%A3o\%20do\%20Cade.pdf>

14 Conforme informações consultadas dos textos originais da comissão de inquérito, no sítio do Senado Federal, disponíveis

<http://legis.senado.leg.br/comissoes/comissao;jsessionid=11BE072E73291EB06CA9F2E95DBEF722?0\&codcol=156 6> Acesso em 10 de Outubro de 2017.

15 Logo após a promulgação da lei foram propostas duas Ações Diretas de Inconstitucionalidade questionando o seu conteúdo, mas em meados de 2016 o STF julgou a modificação da LDA como constitucional.

$16 \quad$ Na vigência da Lei n. 5.988/73, revogada pela atual LDA, o artigo 116 descrevia as funções e o modelo de atuação do chamado Conselho Nacional de Direito Autoral - CNDA, órgão estatal (da esfera Federal) responsável pela 
melhor expresso nas palavras do de WACHOWICZ (2015, p.551), como seguem:

“A Lei 12.853/13 nos artigos 98-B, I, II e parágrafo único, e 109-A passa a assegurar a transparência do sistema de gestão coletiva assegurando aos criadores, interpretes e respectivas representações sindicais e associativas o direito de fiscalização do aproveitamento econômico das obras que criarem ou das quais tenham participação. Devendo, a publicação ser realizada e disponibilizada em sites na internet, apontado as formas de cálculo, critérios de cobrança e de distribuição de valores dos direitos autorais arrecadados sendo vedada a divulgação dos valores individualmente distribuídos aos titulares originários de direitos autorais e conexos, respeitando-se o direito constitucional de intimidade destes."

Um órgão poderoso e efetivo de gestão coletiva de direitos autorais é imprescindível em um momento de tantas mudanças nos mercados da Economia Criativa, envolvendo a disponibilidade de material autoral pela internet. Ainda, os percalços encontrados pelo ECAD em sua trajetória demonstram como o modelo brasileiro ainda não possui uma forma de gestão adequada e preparada para a revolução digital.

\section{A Internet e os Desafios do Mundo Contemporâneo para as Indústrias Criativas}

A história, no direito, tende a se repetir quando se trata de mudança de paradigmas sociais. O direito, baseado nos costumes traduzidos e compilados em jurisprudência e nas leis que, por sua vez, são confeccionadas durante um processo lento e complicado, tem tido dificuldades de acompanhar todas as viradas de comportamento que nossa sociedade vem apresentando. Essa mudança decorre da rigidez do ordenamento jurídico de nosso Sistema Civilista, prevalecente no direito brasileiro, que estabelecem regras ideais de conduta ou condutas esperadas para as relações humanas, cabendo aos juízes aplicar essas regras de conduta ao caso concreto, inclusive rearranjando os parâmetros da lei por meio de princípios e equidade. ${ }^{17}$

fiscalização, organização, assistência e consulta sobre assuntos voltados para a distribuição dos direitos de autores: “Art. 116. da Lei 5.988/73. O Conselho Nacional de Direito Autoral é o órgão de fiscalização, consulta e assistência, no que diz respeito a direitos do autor e direitos que lhes são conexos". (Revogado pela atual Lei de Direitos Autorais)

$17 \quad$ A rigidez das regras no Sistema Civilista se contrapõe ao Sistema Jurídico Anglo-Saxão, que tem por base a formação do ordenamento jurídico decorrente de decisões judiciais e equidade. A rigidez do Sistema Juridico Civilista no Brasil e as raízes de sua formação foram exploradas pelos autores José Carlos Vaz e Dias, Leonardo Sant'Anna e Bernardo Santos da seguinte forma: "The civil law is looked upon as a system whose origin comes from the codification of the Corpus Juris Civilis of Justinian in the Roman Empire blended with rigid dogmas provided for by the influence of the scholasticism of Glossators and the Commentator and the development of Catholicism in Europe. Its main characteristic is the prevailing highly and formal structured codes and laws, often stating idealistic rules and addressing phenomena and legal assets into categories rather than extracting knowledge and rules from the rendering of court decisions, as it happens in the common law system. 
Essa dificuldade por ser claramente observada nas mudanças impostas e que derivam da familiarização dos cidadãos com a utilização da internet.

As interações mais básicas entre seres humanos, quando se transportaram para o meio digital, geraram problemas, como o simples contrato de compra e venda, por exemplo. Com o direito autoral não é diferente e as legislações por todo o mundo vêm enfrentando desafios em se adaptar às novas regras comportamentais do mundo cibernético e da sociedade internauta. As diferenças são constantemente renovadas e, principalmente por conta de o avanço no ramo da tecnologia ser tão rápido, as tendências, formas de utilização e consumo de obras autorais muda a cada dia.

A utilização do domínio digital como principal ambiente de trocas deixa cada vez mais tênues as linhas de divisa de competências e mais difíceis e custosas as formas de fiscalização. Neste ritmo, saem na frente os países com maior estabilidade econômica e maiores investimentos em tecnologia de segurança, e mesmo assim é difícil aplicar as punições das leis autorais nesses países. Tome como exemplo os Estados Unidos. Ali, os crimes de internet voltados para a lei de copyright são difíceis de identificar e de punir, principalmente desde o desenvolvimento das redes de troca de arquivos P2P (peer-to-peer).

O problema da chamada digitization para o mercado literário, por exemplo, é bastante claro, principalmente se tivermos em mente o processo de produção, cópia e reprodução tradicional dos livros. Antes, o plágio, a reprodução ilegal e outros crimes envolvendo infrações de direitos

Since Brazil is a civil law country, the legal culture holds deep roots in the development of the Roman law due to the influence of European codes, especially the French Civil Code of 1804. Most recently, the Roman heritage is expressed in the existing Brazilian Civil Code, which suffered influence from the German Bürgerliches Gesetzbuch of 1900 and from the Codice Civile Italiano of 1942. Further to that, a large amount of provisions from the revoked Brazilian Civil Code of 1916 was incorporated into the existing Civil Code.

As a result, Brazilian scholars and attorneys are trained at the faculty of laws to place each phenomena and "legal asset" into categories, and assess their legal requirements. The assessment exercise aims to assert the phenomena into one of the possible protection by the legal system: property rights, contractual rights or personality rights. This is clearly seen when private property rights are under discussion. Contrary to contract law where any business transaction may be framed as contractual relationship, not every legal asset can be a property matter.

According to the law of the land and the studies of scholars (doctrinal development) on the Theory of Property, there are prior requirements yet to be fulfilled for a "legal asset" to be classified as a real right or property right. Before the requirements are specified, one should understand that property rights deal essentially with the power of a legal owner on a thing or "legal asset". Therefore, owner of "legal matter" holds all available remedies disposed at the Civil Procedural Code and specific applicable laws, such as ex parte preliminary injunctions, temporary restraining orders, search and seizure and indemnification court measures". (DIAS, SANTANNA, SANTOS, 2016. p. 2312 -2334). Veja também ALVES, José Carlos Moreira. Direito Romano. Rio de Janeiro: Forense, 2014, 16. ed., v. 1 and 2. ROSENN, Keith S. "Brazil's Legal Culture: The Jeito Revisited". Florida International Law Journal, Gainesville, v. I, fall/1984. Págs. 1-43. 
autorais sobre textos literários e livros eram apenas questão de prova. Havia um controle físico do material e do que era feito com ele.

Como bem expõe BARLOW (1994), em seu artigo "the Economy of Ideas", as leis de copyright funcionou bem durante anos porque tinha a força da conveniência e os hábitos de compra e utilização das pessoas ao seu lado: era difícil produzir e copiar um livro. Com a chegada da digitalização dos materiais autorais a dificuldade se extinguiu por completo. Isso decorreu do fato de a maior parte das obras literárias ser encontrada em formato digital na internet. Mas a questão não é apenas a facilidade com que se copia o livro, mas sim a falta de meios de fiscalização destas cópias.

Ainda citando ideias do texto do mesmo autor, o problema maior da digitalização é que, quanto mais a tecnologia se expande e evolui, mais complexo fica a determinação de critérios de diferenciação da obra autoral da mera fala, da mera expressão de ideias, sendo que esta última não pertencente ao âmbito de proteção das leis autorais pelo mundo (BARLOW, 1994).

Os suportes ${ }^{18}$ estão cada vez mais distantes do tradicional livro de capa dura e do vinil que era comercializado em lojas de discos. Além disso, a própria sociedade e as pessoas podem ser confundir por essa diluição da forma física, adotando corriqueiramente obras de terceiros como mera informação, o que é na verdade constituem uma reprodução e violação dos direitos sobre uma obra intelectual licitamente desenvolvida por um trabalho autoral. ${ }^{19}$ Como todos os ramos das indústrias criativas, sofreu com a desmaterialização a indústria fonográfica, que se viu obrigada a repensar todas as suas formas de monetização, ameaçadas pela chamada "pirataria" musical, e a indústria cinematográfica e de produção televisiva, que nos anos 2000 travaram uma árdua batalha contra a pirataria e a reprodução inadequada de conteúdo na internet.

Até o presente momento ainda são muitas as dificuldades enfrentadas pelos grandes sujeitos do mercado criativo, pois a transformação dos negócios, que antes objetivavam a venda de produtos

18 Hoje em dia existem blogs, vlogs, grupos online de discussão literária, dentre outras formas de expressão de opinião e ideias e de produção literária, que permite uma reprodução e circulação ampla de obras autorais. Inclua-se a reprodução às imagens, fotografias e outras obras classificadas como estéticas e intrinsecamente relacionadas às obras literárias. Todas estas formas podem ser consideradas formas de suporte para material autoral? Como fazer a diferenciação das ideias e da produção autoral em uma época em que cada vez mais os suportes ficam menos físicos e mais próximos do pensamento ou da fala?

19 Há postagens em blogs que por conta da temática e da repercussão que tomam, podem ser confundidos com meras notícias, mas ainda assim, têm o toque da narrativa de seu autor e o suporte daquele texto é de domínio pessoal "localizado" em meio a maior rede de informações do planeta. 
e hoje focam na venda de serviços pagos através de mensalidade, não está imune às críticas e a volatilidade das vontades do público consumidor ${ }^{20}$.

\subsection{Novos Modelos de Negócio Digital}

Com a consideração de todos os problemas já apresentados, foram surgindo novas ideias de fomento e monetização dos negócios do entretenimento e, diversos projetos empreendedores de novas formas de reprodução de material autoral na internet surgiram desde a criação das redes de compartilhamento peer-to-peer. Dentre tantos exemplos, podemos analisar as redes de compartilhamento controlado de material autoral criadas pela Creative Commons Organization, e a criação da reprodução musical via streaming, que apesar de ser um serviço fornecido por diversos empresários, é protagonizado mundialmente pelas companhias Youtube, Spotify e Netflix.

Creative Commons (doravante denominado Creative Commons ou CC) é uma organização sem fins lucrativos que conquistou espaço e influência em todo o mundo, inclusive no Brasil. O diferencial da Creative Commons vai além da tecnologia desenvolvida e disponibilizada de licenças de uso. Na verdade, a disponibilização de licenças para uso gratuito reflete o ideal, a missão e o objetivo desta forma de distribuição.

O lema da organização é manter os direitos do autor, através das limitações de cada licença de direitos CC, ao mesmo tempo em que permite o livre acesso e disponibilização das obras pelos usuários do site. Em 14 anos já são mais de 800 milhões de obras registradas através das licenças, que têm vários tipos e níveis de restrição de direitos. ${ }^{21}$

A missão escolhida pela organização é maximizar o potencial da criatividade e da inovação, através do oferecimento de suporte e infraestrutura legais para que os autores dividam suas obras com o público usuário. Desta forma, pretende cumprir com as palavras estampadas no site: “Keep

20 Um exemplo de grande relevância destas dificuldades é a queda de rentabilidade que a Disney vem percebendo desde o surgimento dos serviços de streaming na internet. O grande império de entretenimento criado por Walt Disney há bastante tempo depende da renda que geram seus canais de televisão (como ESPN, Disney Channel e $\mathrm{ABC}$ ) no território dos EUA e no mundo. No entanto, com o crescimento de sites de streaming como Youtube, cada vez menos pessoas investem em um pacote de TV paga e o resultado foi de queda acima do esperado para o grande conglomerado de entretenimento americano. Para mais informações ver o sítio: http://time.com/4567375/disneyearnings/?utm_source=feedburner\&utm_medium=feed\&utm_campaign=Feed\%3A+time $\% 2$ Fbusiness+\%28TIME\%3A +Top+Business+Stories\%29.

21 Informações retiradas do site institucional da Creative Commos em: <http://www.creativecommons.org/about/history> Acesso em: 10 de Outubro de 2017. 
the internet creative, free and open"22.

Mas como o sistema criado pela Organizaçao Creative Commons pode ajudar o autor a driblar as dificuldades apresentadas pelo acesso a internet? Na verdade, é um erro comum pensar que as licenças de $\mathrm{CC}$ vieram como uma alternativa às leis de copyright e de direito autoral. Essas leis autorais são aplicáveis e permeiam todo o sistema criado pela Creative Commons, o que fazem as licenças é flexibilizar seus termos de acordo com a vontade do autor.

Como estas permitem certo nível de liberdade, é simples determinar que a obra seja acessada apenas para fins não lucrativos, que ela seja copiada parcial ou totalmente, que ela possa ser ou não modificada por usuários, dependendo da vontade do autor. As licenças funcionam como um contrato, sobre o qual o autor do material autoral - contratado - define os termos e o usuário de internet - contratante - deve obedecer àquelas regras para ter acesso à obra.

A principal problemática deste instrumento é que, em última análise, não extingue os problemas enfrentados pelas leis de direito autoral no meio digital com relação à fiscalização do uso. O próprio site da organização possui uma página dedicada exclusivamente ás propostas de alteração legislativa que a organização e seus usuários entendem pertinentes.

A lei autoral, inclusive, baseia toda a estrutura das licenças. Afinal, se não fossem as limitações criadas por elas, não haveria porque na existência destes instrumentos, que se dedicam a flexibilizar proibições encontradas nestas legislações. Esta será aplicada, inclusive, para solucionar eventuais disputas acerca do que foi licenciado, ou seja, no fim do caminho a forma de resolução para eventuais conflitos será, justamente, um embate judicial, baseado na lei autoral e com as mesmas dificuldades de prova e processamento que todos os processos envolvendo a internet possuem. São as leis autorais que determinam como e em que medida será punido o usuário que utiliza de forma inadequada o trabalho publicado.

A licença pode ser considerada como um mecanismo para assegurar ao autor que o usuário da internet tem consciência dos direitos envolvidos e que o que está usando ou lendo é um trabalho intelectual produzido por terceiro, que deve ser respeitado de acordo com os limites impostos. Não obstante, no conceito das licenças gratuitas, não há uma garantia efetiva que os direitos autorais sobre o trabalho de terceiro serão respeitados pelo licenciado, pois o objetivo das licenças creative

\footnotetext{
22 Em tradução livre "manter a internet criativa, gratuita e aberta". Informação retirada do site institucional da
} Creative Commos em: <http://www.creativecommons.org/about/history> Acesso em: 10 de Outubro de 2017. 
common não é assegurar a eficácia dos direitos, mas promover a divulgação e o acesso das obras. ${ }^{23}$

O streaming, por sua vez, surgiu como uma alternativa remunerada de adaptação do comércio de músicas, filmes e demais formas de audiovisual, antes comercializadas através dos discos de vinil e dos CDBs, DVD's e através dos canais de TV a cabo, para a compactação própria dos aparelhos compatíveis com arquivos em "mp3", "mp4" e com acesso à internet - ou seja, telefones celulares, tablets, notebooks e outras tantas ferramentas corriqueiras para a sociedade moderna.

Após a descoberta de novas formas de compactação das obras em arquivos próprios dos sistemas digitais, as indústrias criativas, e aqui utilizamos de forma mais aprofundada o exemplo da indústria fonográfica, não foram capazes de atender as demandas sociais por novas formas de fruição dos seus produtos. A princípio, o download de músicas em redes de compartilhamento na internet era completamente clandestino, a medida que não era a indústria quem disponibilizava os arquivos, mas sim os usuários que os extraíam de CD's para produzir cópias privadas que pudessem ser reproduzidas em novos dispositivos, como os próprios computadores, aparelhos de reprodução de “mp3”, DVD's, dentre outros.

Houve então a classificada grande crise da "pirataria" mundial. O ato de carregar arquivos audiovisuais da internet passou a ser algo socialmente aceitável, ao mesmo tempo em que era uma prática que ameaçava as gravadoras e desvalorizava o trabalho dos interpretes, autores e compositores. Entende-se que esse comportamento dos usuários de obras autorais nasceu do não atendimento de novas necessidades que surgiram com a comercialização da internet. $\mathrm{O}$ mercado

23 Nesse mesmo raciocínio, existem questionamentos sobre o uso e eficácia de proteção ao software livre. De forma mais aprofundada, muitas dúvidas surgem quando um desenvolvedor de software utiliza um "software livre" para alcançar um novo desenvolvimento a ser colocado no mercado ou mesmo ao utilizar uma biblioteca privada. Qual seria o parâmetro de utilização e as penalidades por esse uso extensivo e fora da licença do software livre? Para mais informações sobre esse assunto, deve-se remeter ao artigo publicado por José Carlos Vaz e Dias denominado "O Software Livre Sob a Perspectiva da Inovação tecnológica: Conceito, Limites e Peculiaridades Jurídicas. ” PIDCC, Aracaju, Ano III, Edição $\mathrm{n}^{\mathrm{o}}$ 07/2014, p.178 a 210 Out/2014. Disponível em http://pidcc.com.br/artigos/072014/07082014.pdf. Esse artigo aborda importante questões relativas ao software livre e o software proprietário, tais como: Seria o "software livre" comercializável, por meio do licenciamento de direitos e disponibilização onerosa ao público? Seria considerado "livre" um software conjugado de esforços intelectuais de várias pessoas e da compilação de softwares pré-existentes e de determinadas bibliotecas, utilizando uma base livre (sejam esses proprietários e/ou disponibilizados livremente no mercado)? Pode ele ser comercializado onerosamente? Qual é a diferença entre software livre e software de código aberto? Estaria o "software livre" violando os princípios do software proprietário, baseados na autorização prévia para exploração comercial ou não comercial? Estaria o software proprietário violando as regras do livre acesso aos softwares disponibilizados em plataformas livres? Seria um procedimento reconhecido pelo direito o desenvolvimento de um software decorrente da transformação criativa e da reelaboração de material intelectual anterior? 
consumidor possuía os meios de atender por si só, e de graça, demandas que foram por muito tempo ignoradas pelos produtores de conteúdo e que surgiram da inovação tecnológica dos meios de reprodução destes. Deve-se relevar neste ponto que as "demandas ignoradas pelos produtores de conteúdo" decorreram do conceito prevalecente da segurança jurídica dos titulares sobre as obras baseadas em direitos proprietários. Esse conceito não acompanho a divulgação extensiva das obras em meios digitais. Aliás, por ser proprietário, o conceito baseava-se no acesso limitado e respeitoso aos direitos de propriedade.

A possibilidade de download das músicas por sites de venda digital marcou uma nova postura da indústria fonográfica em relação ao problema da digitalização e da distribuição não autorizada das obras na internet, mas, ainda assim, foi alternativa paliativa para o problema, que já envolvia a participação direta do consumidor nas definições dos limites comerciais: o público já não aceitava mais pagar os valores impostos pela indústria, tendo em vista a opção de livremente dividir a música de graça através dos downloads.

Novos empreendedores, no entanto, percebendo que havia uma demanda social a ser atendida, passaram a promover um serviço de disponibilização das músicas, com autorização expressa dos titulares de direitos autorais, através de conexões de internet, de forma que a tecnologia não conferia a propriedade dos arquivos digitais, apenas a possibilidade de reproduzi-los quando da vontade do usuário, mediante um cadastro e pagamento de mensalidade.

A Spotify se tornou pioneira do serviço no mundo, pois foi uma das primeiras a oferecer uma conta gratuita, com limitações e anúncios de patrocinadores sem o controle do usuário, como atrativo para a contratação do plano mensal pago. O modelo, no entanto, ainda é demasiado inovador para estar imune a críticas e percalços, de forma que ainda é questionada a forma de remuneração e a transparência da contratação dos licenciamentos musicais.

Da mesma forma a Netflix investiu no streaming de filmes e séries e recentemente alcançou uma posição de destaque no mercado de audiovisual, mas não sem encontrar resistência inicial das emissoras e produtoras. O serviço consiste, da mesma forma que no Spotify, do pagamento de mensalidade em troca do acesso a um repertório que fica à disposição do usuário através da conexão de internet.

O Youtube, por sua vez, funciona de forma diferente dos dois últimos exemplos, uma vez que é um sítio de livre acesso a qualquer usuário da internet e vêm recebendo diversas críticas pelas 
políticas de direitos autorais estabelecidas pela companhia. Os termos de uso do site deixam claro que o usuário que sobe o conteúdo é responsável pelo atendimento às leis de direito autoral pertinentes, repassando a responsabilidade sore a fiscalização ficando esta a cargo da rede de visitantes, que podem denunciar conteúdo a qualquer tempo.

Quanto ao pagamento de royalties e direitos de execução pública dos conteúdos do Youtube, a situação ainda não foi definida, justamente por conta da divergência acerca do enquadramento das atividades via streaming como exemplo de execução pública. Novos modelos de negócio do mercado fonográfico têm enfrentado a mesma dificuldade acerca do pagamento de direitos aos autores, artistas e titulares de direitos conexos, principalmente porque se trata de um novo cenário que ainda não foi regulado pela lei e ainda não tem práticas consolidadas de mercado. A novidade da internet, portanto, traz novas dificuldades e desafios para o direito autoral, mas novas oportunidades de mercado e para a democratização de elementos culturais, como a música.

\subsection{Novas Formas de Pensar o Direito Autoral}

O momento atual de desenvolvimento social e econômico relaciona-se a um momento de mudança de mentalidade, que apresenta um foco maior no bem-estar social e coletivo, em que cada vez mais se valoriza o acesso o à cultura e à informação, pois são classificadas ferramentas de desenvolvimento social e econômico (SCHREIBER, p. 5-15).

O direito do coletivo tem ganhado poder sobre o direito do indivíduo, e o modelo das leis autorais passa a ser compreendido nesta situação sob uma perspectiva social na funcionalização desse direito, que se encontra precisamente explicitado nas palavras de (SCHREIBER, p.5-6), da seguinte forma:

"Como se vê, a modificação é essencialmente de função, mas a inserção de
interesses sociais no elemento funcional gera, por via reflexa, uma remodelação da
estrutura do direito de propriedade. A propriedade passa a ser vista não mais como
direito absoluto ou "poder inviolável e sagrado" do proprietário, mas como
situação jurídica subjetiva complexa em que se inserem direitos, deveres, ônus,
obrigações.10 Esses deveres não equivalem àqueles de caráter negativo,
considerados externos ao domínio e impostos ao proprietário em nome do interesse
público ou do poder administrativo de polícia. São deveres de caráter também
positivo11 atribuídos ao titular do domínio como consequiência do próprio direito
de propriedade; sua origem não se situa em um fator externo qualquer que
justifique a limitação do exercício do direito, mas, ao contrário, encontra sua 
gênese no interior do próprio instituto, mais precisamente em seu elemento funcional.

Esclareça-se que funcionalizar a propriedade ao atendimento de interesses sociais não significa, de modo algum, propor o aniquilamento dos direitos individuais ou pregar a negação da propriedade privada. Muito pelo contrário. A função social, impondo ao proprietário a observância de determinados valores sociais, legitima a propriedade capitalista e a compatibiliza com a democracia social que caracteriza os sistemas políticos contemporâneos.12 O proprietário permanece como beneficiário imediato, e quase sempre predominante, do domínio; apenas se impõe a ele que exerça o seu direito atendendo também aos interesses sociais. A propriedade se mantém privada, mas se afasta da definição individualista de "poder absoluto do proprietário" para buscar na conformação ao interesse social a sua legitimação, a razão e o fundamento de sua proteção jurídica.13 Nessa nova concepção, a propriedade passa a ser tutelada apenas na medida em que observe os interesses sociais relevantes. A conduta do proprietário e a tutela dos seus interesses passam a estar condicionadas ao atendimento da função social da propriedade.14 Não se oprime o indivíduo, mas se exige dele alguma atenção aos anseios mais graves do organismo social em que se insere."

Nessa perspectiva, os direitos autorais não podem ser mais vistos essencialmente sob uma perspectiva de lucro para proliferação da criação, ou seja, traz uma abordagem mercadológica.

Mesmo com essa nova concepção, entende-se ser necessário aprofundar as novas relações humanas criadas e, assim, encontrar um meio termo entre a ideia de material liberado e gratuito "sem dono" e a segurança do autor que produz arte, literatura, inovação e novas formas de exposição da criatividade. Os direitos a informação, à cultura, as próprias dificuldades impostas pela internet e todas as circunstâncias do mundo em que vivemos têm nos mostrado que a lei cada vez mais rigorosa e mais restritiva tem cada vez menos eficácia prática.

O que é imperativo para alterar a situação atual de instabilidade do direito autoral não parece ser apenas uma alteração legislativa. Deve-se envolver também uma adequação do comportamento da sociedade aos padrões éticos esperados de uma comunidade contemporânea. A fiscalização da internet deve acontecer por duas vias, de fora para dentro - sendo imperativa a melhoria e implementação de novas tecnologias e políticas públicas para maximizar a eficácia da fiscalização por parte de órgãos competentes - e de dentro para fora - com a participação dos usuários que escolherem se utilizar da internet de forma legal e ética.

Para que isso aconteça é preciso que haja comoção, principalmente daqueles que formam a opinião, que disseminam a informação e a cultura, muitas vezes os próprios criadores de material 
autoral. Torna-se relevante pontuar para a sociedade a importância para uma preocupação com o futuro, com a adequação aos novos tempos em que não é mais possível focar apenas nos seus próprios direitos, mas da comunidade que nos cerca. Com isso, busca-se minimizar as proibições e maximizar a consciência para almejar a inserção do direito autoral a uma nova Era, em que novos modelos de negócio revitalizam a forma de atribuir remuneração pelo trabalho autoral e, ao mesmo tempo, propiciar o maior acesso aos bens culturais. O aceso extensivo aos bens culturais pode inclusive propiciar lucratividades para os autores intelectuais, criando para eles novas oportunidades de negócios e explorações econômicas como criações de subprodutos (merchandising) e atuação comercial em novos mercados receptores de obras intelectuais.

\section{A Ascensão aos Direitos Culturais e suas Implicações Jurídicas}

Previstos na Constituição da República Federativa do Brasil, os Direitos Culturais ou o acesso extensivo às obras intelectuais de impacto cultural podem ser considerados direitos fundamentais e permeiam diversos artigos do texto constitucional. Além da previsão brasileira, são reconhecidos também internacionalmente, através de tratados internacionais ${ }^{24}$ e da ação da Organização das Nações Unidas. ${ }^{25}$

Na Constituição Federal de 1988, podem ser elencados os artigos 23, 24 e 30 que especificam as competências legislativas de cada ente federativo, estando presentes os deveres de zelar pelos documentos, as obras e outros bens de valor histórico, artístico e cultural e proporcionar os adequados meios de acesso à cultura (SOUZA, 2012, p.68)

A seção II da Carta Magna, por sua vez, é totalmente dedicada à previsão cultural, determinando que o Estado deve garantir aos cidadãos o pleno exercício dos direitos culturais, através do acesso às fontes da cultura nacional, além de apoiar e incentivar a valorização e a difusão das diversas manifestações culturais presentes no território Brasileiro, conforme previsto no Art. $215^{26}$.

\footnotetext{
24 Como, por exemplo, a Convenção Americana de Direitos Humanos de 1969 e Convenção para a Salvaguarda do Patrimônio Cultural Imaterial de 2003, a serem mencionados em maior detalhe ao longo do presente trabalho.

25 Principalmente através da UNESCO, como por exemplo a realização da Convenção sobre a proteção e promoção da Diversidade das Expressões Culturais de 2005.

26 Art. 215. da Constituição Federal: "O Estado garantirá a todos o pleno exercício dos direitos culturais e acesso às fontes da cultura nacional, e apoiará e incentivará a valorização e a difusão das manifestações culturais.

$\S 1^{\circ} \mathrm{O}$ Estado protegerá as manifestações das culturas populares, indígenas e afro-brasileiras, e das de outros
} 
Ao longo da mencionada seção e seus três artigos, são elencados os bens considerados como patrimônio cultural, instituído o Sistema Nacional de Cultura, além da previsão de que medidas sejam tomadas pelos governos em prol da defesa e valorização do patrimônio cultural do país, do incentivo a produção, promoção e difusão desses bens coletivos, da valorização da diversidade e, principalmente, da democratização do acesso à forma de expressão dos povos brasileiros.

Os incisos IX, XXVI e XXVIII do art. 5º da Magna Carta de 1988 também são tocantes aos direitos culturais, na medida em que pretendem assegurar a liberdade de expressão, tratam da constituição dos próprios direitos autorais e da participação popular nas ações do Estado acerca da cultura. Essas disposições constitucionais representam uma preocupação com as condições que promovem a produção cultural, ou seja, protegem a disseminação das ideias, promovem a valorização do trabalho intelectual autoral e a participação social como exercício da cidadania (SOUZA, 2012, p.69).

São diversos os artigos que permeiam a questão cultural na Constituição Federal, mas é necessário destacar também o Art. $227^{27}$, que institui o direito a cultura como direito fundamental da criança e do adolescente, como não poderia ser diferente, para garantir que a valorização da cultura não será ultrapassada com a mudança das gerações.

Claramente o Constituinte originário se preocupou de forma legítima com o reconhecimento da cultura como peça fundamental para a construção da sociedade que idealizava para o país. Não poderia ser diferente na medida em que as expressões artísticas e autorias dos povos, que constituem a nação brasileira, contribuem para o desenvolvimento do cidadão e permitem que desenvolva o sentimento de pertencimento que o faz se preocupar com a manutenção da comunidade onde vive e com quem se relaciona, gerando crescimento socialmente sustentável através do exercício da cidadania, restando claramente explicitado nas palavras do doutrinador SOUZA (2012, p. 159) como segue:

“A amplitude dos efeitos pessoais e sociais dos direitos culturais indica que não há como cumprir os objetivos fundamentais da República de edificação de uma sociedade livre, justa e solidária, de assegurar o desenvolvimento inclusivo e

grupos participantes do processo civilizatório nacional."

27 Art. 227. da Constituição Federal: "É dever da família, da sociedade e do Estado assegurar à criança, ao adolescente e ao jovem, com absoluta prioridade, o direito à vida, à saúde, à alimentação, à educação, ao lazer, à profissionalização, à cultura, à dignidade, ao respeito, à liberdade e à convivência familiar e comunitária, além de colocá-los a salvo de toda forma de negligência, discriminação, exploração, violência, crueldade e opressão." (grifos nossos) 
promoção do bem geral sem a sua máxima concreção. A igualdade cultural é condição para o diálogo e convivência harmoniosa e, o diálogo efetivamente livre é essencial em uma sociedade plural. Este é o desígnio constitucional, ao qual tanto o Estado como os cidadãos e a sociedade estão vinculados. "

A valorização dos direitos culturais, no entanto, não é um fenômeno exclusivamente brasileiro, possuindo uma história de ascensão no cenário internacional, com a valorização dos direitos fundamentais e as considerações acerca do bem-estar dos seres humanos. Em 1948, foi publicada a Declaração Universal dos Direitos Humanos da ONU, que aborda especificamente a questão cultural quando, em seu Art. 22, determina que todas as pessoas, como membros da sociedade, têm direito de exigir a satisfação dos seus direitos econômicos, sociais e culturais indispensáveis, sob responsabilidade de sua nação e da cooperação internacional (ONU, 1948, art. 22).

Além de diversos outros pactos internacionais generalistas, firmados em prol dos direitos dos homens, em 1966 foi publicada a Declaração da Unesco sobre os Princípios de Cooperação Cultural, que foi considerado o primeiro passo para a institucionalização da questão cultural na Organização das Nações Unidas e em 1969, foi firmado o Pacto de São José da Costa Rica, resultante da Convenção Americana sobre Direitos Humanos, que de maneira geral atestam a importância de comprometimento dos Estados com a satisfação dos direitos econômicos, sociais e culturais de seus cidadãos.

Os documentos mais recentes que foram editados no âmbito internacional para reforçar o debate sobre direitos culturais são a Declaração Universal sobre Diversidade Cultural de 2001 e a Declaração de Istambul de 2002 das quais, surgiram, respectivamente, a Convenção da Diversidade das Expressões Culturais em 2005, que reconheceu a relação direta entre os bens culturais e o desenvolvimento nacional dos países, e a Convenção para Salvaguarda do Patrimônio Cultural Imaterial em 2003.

A disseminação de conhecimento e a informação têm transformado a forma como as sociedades lidam com questões locais e internacionais, não há mais um limite tão claro entre estes dois âmbitos, o que tem gerado campanhas mundiais pela internet, até mesmo causando discussões sobre os limites da intervenção de uma cultura sobre a outra ${ }^{28}$.

\footnotetext{
28 Existem campanhas na internet em prol de mudanças culurais de preceitos mitas vezes estabelecidos por crenças ou religiões e diferenças regionais, como os protestos para proibir que cachorros (comumente animais de estimação no no ocidente) sejam consumidos como alimento em regiões da Ásia, por exemplo, porém, estas são
} 
Interligado diretamente com a questão do direito ao acesso da informação, está o direito de acesso à cultura, o direito de manifestação cultural, os direitos de cultura cidadã de forma geral, uma vez que a internet é, hoje em dia, o grande palco de manifestações sociais mundiais e uma grande ferramenta de disseminação, tornando possível o intercâmbio entre pessoas e suas diferentes culturas com a mitigação das barreiras geopolíticas mundiais.

É essencial, não só para a sadia interação entre os povos, mas também para a formação de cada indivíduo, a proteção e disseminação da cultura. Isto porque o entendimento e aprofundamento do próprio conhecimento cultural ajuda na criação da identidade individual e da identidade coletiva, enquanto, ao mesmo tempo, o conhecimento sobre as demais culturas permite que estas interajam com respeito e equidade.

A Organização das Nações Unidas para a Educação, a Ciência e a Cultura (UNESCO), no entanto, alerta para o problema maior, qual seja a realidade de que ainda vivemos em um mundo em que há desigualdade no acesso aos direitos culturais:

"O momento é de reconhecimento dos direitos culturais como necessidade básica e direito dos cidadãos, o que conduz à busca de uma agenda integrada com as políticas sociais e de desenvolvimento. Em que pesem as tendências recentes, seus impactos ainda não foram suficientes para reduzir o quadro de desigualdades no acesso à produção cultural e é fundamental cuidar para que, ao contrário, o crescimento econômico não faça com que tais desigualdades sejam ainda mais exacerbadas." (UNESCO)

Segundo SOUZA (2012, p.94) os direitos culturais no Brasil podem ser divididos entre quatro perspectivas: da participação na vida cultural comunitária, do acesso à cultura, do incentivo às diversas manifestações culturais e, finalmente, da proteção e do investimento no patrimônio cultural brasileiro.

O direito de participação na vida cultural é essencial para o exercício dos demais direitos culturais. O objetivo é impedir que haja exclusão de qualquer dos indivíduos de uma comunidade das atividades, promovidas pelo Estado e pela iniciativa privada, relacionadas à cultura. A recusa de participação deve ser voluntária e, por si só, trata-se de uma forma de participação cultural (SOUZA, 2012, p.95) Dentro do escopo da participação na vida cultural está também o direito de

questões culturais e não comportam apenas uma forma de visualização da questão, reportagens disponíveis em <https://secure.avaaz.org/campaign/po/stop_the_puppy_slaughter_loc/> 
participação nas decisões envolvendo a criação e manutenção de políticas públicas culturais, direito que é garantido aos cidadãos pela Constituição Federativa do Brasil. ${ }^{29}$

Infelizmente, no Brasil, este direito ainda faz parte da realidade de poucos cidadãos, levando em consideração que aqueles pertencentes a grupos minoritários ${ }^{30}$, ainda não possuem a garantia de participação livre da vida cultural de sua comunidade de escolha. Além de ainda sofrerem com a discriminação, que impõe barreiras sociais à vivência plena de seus direitos, também não possuem igualdade de condições no gozo de seus direitos culturais. São diversas as desigualdades que promovem este problema, que vão desde questões regionais, até as profundas discrepâncias entre o ensino público e o privado e outras carências sociais e econômicas.

Para a efetivação progressiva dos direitos culturais é preciso eliminar barreiras que ainda restringem o acesso à cultura, tanto aquela própria do indivíduo como às outras culturas diversas. É preciso que haja um engajamento real na promoção de bens e serviços culturais nas cidades e estados, garantindo a todos a sua fruição. O compartilhamento, difusão e produção cultural, sem qualquer discriminação, são desafios para governos e iniciativa privada, que devem ser superados através das políticas públicas de cultura. (KAUARK, 2013, p.8)

\subsection{Interposição entre Direitos Culturais e os Direitos de Autor}

O material autoral é também uma manifestação cultural que agrega conhecimento, promove o pensamento livre, o aprendizado - mesmo que indiretamente - e deve ser valorizado como agente promotor de cultura, porém, o problema reside justamente na ponderação destes dois direitos: o direito do autor de receber uma remuneração justa pelo fruto de seu trabalho e o direito da sociedade de ter acesso aos diferentes meios de promoção da cultura.

Há autores, como BRANCO (2007, p.130), que entendem que a forma atual de proteção do

\footnotetext{
29 Constituição da República Federativa do Brasil, Art. 50 "Todos são iguais perante a lei, sem distinção de qualquer natureza, garantindo-se aos brasileiros e aos estrangeiros residentes no País a inviolabilidade do direito à vida, à liberdade, à igualdade, à segurança e à propriedade, nos termos seguintes: LXXIII - qualquer cidadão é parte legítima para propor ação popular que vise a anular ato lesivo ao patrimônio público ou de entidade de que o Estado participe, à moralidade administrativa, ao meio ambiente e ao patrimônio histórico e cultural, ficando o autor, salvo comprovada má-fé, isento de custas judiciais e do ônus da sucumbência;”

$30 \quad$ Podem ser considerados exemplos de grupos minoritários no Brasil: os afrodescendentes, indígenas, ciganos, pessoas com deficiência, homossexuais, mulheres, populações rurais, dentre outros. É importante frisar que a minoria não significa propriamente que seus números sejam reduzidos comparados com a população total do país, mas sim com relação a sua representatividade oficial e ao atendimento de seus anseios e direitos da personalidade.
} 
direito autoral opera na contramão das tendências globais de exaltação da cultura como forma de ensino e difusão da educação, justamente por conta das restrições de acesso a determinadas obras, para fins de proteção do direito autoral e dos rendimentos da obra.

$\mathrm{O}$ advento da internet tornou muito controversa a proteção tradicional dos direitos autorais, principalmente diante de uma movimentação social a favor do poder de ter acesso a qualquer material, abertamente, de forma gratuita e sem limitações. A internet assegura poderes ao indivíduo que se vê apto a dividir material livremente e, muitas vezes, sem punição, por conta da precariedade da fiscalização exercida nos meios digitais. Dá-se a falsa impressão de que a proteção conferida pela lei autoral é mera formalidade.

Uma vez que a obra intelectual e artística na Internet não possui mais uma apresentação única de produção integral do autor, mas agora é diretamente interligada à atuação coletiva e, muitas vezes, anônima de uma comunidade inteira na internet, podemos dizer que as noções de autor e leitor estão cada vez mais próximas e mescladas, tornando ainda mais obsoleta a classificação e proteção da LDA da forma como pensada em sua confecção (IRATI, 1998, p.190191).

As modificações no perfil de usuários e nas formas de uso da internet fizeram com que toda uma nova filosofia de pensamento e ações tomasse conta do ambiente digital, com movimentos como o do Software Livre e da Cultura Hacker, em prol do acesso e disseminação de informações livres pela rede.

"E. Gabriella Coleman (2010) usa a expressão 'cimento cultural' para definir o
significado que tem a liberdade de produção e de compartilhamento de conteúdos
culturais e conhecimento na rede, mostrando o quanto é indispensável, para
programadores, artistas, cientistas, educadores, entre outros, a garantia de abertura
cultural do ciberespaço. É só com essa abertura e liberdade que as trocas podem
fluir, de modo que não só cada parte, mas o todo social saiam ganhando nas trocas.
E quanto mais isso acontece, como em um círculo virtuoso, mais abertura e
liberdade estimulam a produção de novos elementos culturais a partir dos já
existentes." (COLEMAN, 2010 apud. PRETTO; CORDEIRO; OLIVEIRA, 2013,
p.34)

Como bem elucida BRANCO (2007, p.22) em seu artigo sobre o assunto, a visão sobre o direito autoral precisa ser alinhada ao conceito de função social da propriedade, principalmente quando o conteúdo do material em questão é importante para a disseminação de cultura no país, 
como segue:

\begin{abstract}
"Parece que, hoje em dia, o valor das coisas está intrinsecamente ligado ao preço que podem ter. E não só o preço cumpre o papel de "guardião" do acesso aos bens culturais, como um posto de pedágio: também a lei e a tecnologia podem ser grandes entraves ao acesso ao conhecimento. Depois da revolução industrial - que patrimonializou as relações jurídicas até pelo menos a primeira metade do século XX - vivemos hoje uma revolução tecnológica que tem de conviver com determinados fatos e acomodá-los numa difícil equação: ao mesmo tempo em que a riqueza se desmaterializou, ou seja, os bens não materiais, intangíveis, são mais valiosos do que os bens físicos, o direito exige a funcionalização dos institutos, o que significa que a propriedade de tais bens não pode ser exercida arbitrariamente, devendo atender sua função social. Na prática, isso significa que os titulares de bens intelectuais - direitos autorais, marcas, patentes - não podem utilizá-los indiscriminadamente. Será necessário que observem como tais bens atendem a função a que se destinam na sociedade."
\end{abstract}

Apesar das opiniões apresentadas sobre o acesso à internet e seu papel com relação à construção e produção cultural, acredita-se ser possível, através dos novos modelos de negócio e da tecnologia, além da conscientização dos autores e artistas envolvidos, satisfazer as necessidades sociais e, ao mesmo tempo, proporcionar a devida remuneração quando a produção artística fizer jus à proteção autoral. Isto, no entanto, só será possível revisitando a legislação autoral e repensando o instituto dos direitos autorais, para garantir que o acesso a cultura e a criação intelectual não sejam ameaçados por antigos paradigmas e formas engessadas de monetização dos negócios na Indústria Criativa.

\title{
CONCLUSÃO
}

A problemática do direito autoral na atualidade não decorre somente de uma inadequação jurídica do ordenamento vigente sobre as obras intelectuais. Pode-se observar também aspectos sociológicos, em vista de um comportamento social de desrespeito à ética e à necessidade de observância dos limites dos direitos assegurados aos criadores e titulares das obras intelectuais.

O autor deve proteger sua obra, preservando os seus direitos morais e patrimoniais, pois a obra é efetivamente fruto de trabalho inerente à sua personalidade. No entanto, é preciso entender que determinados conteúdos devem atender a sua função social, de forma a torna-los acessíveis à população para buscar o a dignidade humana, o pleno desenvolvimento da pessoa, a promoção da cultura e o desenvolvimento econômico e social. 
Neste sentido, pode-se apostar em alterações legislativas para o aprimoramento do arcabouço jurídico de proteção e exploração dos direitos autorais, bem como propostas educativas para os respeitos aos direitos da propriedade intelectual. Mudanças na legislação são necessárias, principalmente considerando a Lei de Direitos Autorais Brasileira que ainda peca em diversos aspectos e gera confusão mesmo fora do meio digital, mas a real necessidade está na mudança de raciocínio e hábitos sobre a proteção e utilização de material autoral.

Para balancear estes dois direitos - acesso adequado à cultura e proteção aos desenvolvimentos intelectuais protegidos pelo direito autoral - torna-se necessários que o Estado preste especial atenção às políticas públicas, principalmente voltadas para a Cultura e a Educação, garantindo que o acesso aos bens culturais, inclusive de produção autoral, seja o mais amplo e benéfico possível à sociedade. A participação das grandes editoras e produtoras neste sentido também é crucial, tendo em vista que é responsabilidade de todos os envolvidos o atendimento dos direitos culturais dos seres humanos elencados no presente artigo.

Ao mesmo tempo, é preciso criar opções cada vez mais interativas e interessantes aos usuários da internet para acesso as obras autorais, de modo que a pirataria perca espaço a ser conquistado por novos modelos de negócio digital, responsáveis pela recapitalização dos direitos autorais de forma diferente, porém efetiva. É preciso que os elementos principais de cada nicho das indústrias criativas estejam conscientes de que as formas antigas de arrecadação não se aplicam mais aos padrões sociais atuais, se tornaram obsoletos e precisam ser repensados.

As indústrias literária, fonográfica, cinematográfica e de produção visual precisam tomar iniciativas concretas de renovação, vislumbrando as peculiaridades de cada indústria e possíveis formas de proteção das criações sem restringir inadequadamente o acesso ao conhecimento e às obras intelectuais.

O objetivo do presente artigo era determinar um escopo em que os direitos autorais e os direitos culturais possam conviver protegidos pelo mesmo ordenamento jurídico e ambos respeitados pela sociedade, que é parte integrante da fiscalização e efetivação de os mencionados direitos. O que é possível concluir com todo o exposto é que, apesar de necessárias, as modificações legislativas pretendidas ao regime de direitos autorais no Brasil não são suficientes para renovar a estima das indústrias criativas.

Para que haja verdadeira renovação, com valorização do trabalho dos autores, interpretes e 
demais artistas envolvidos nos processos criativos, é necessário mudar a forma como se enxerga o direito autoral, adaptá-la as novas formas de interação social, adequá-la à função social que deve permear todos os direitos e então transformar o direito autoral em uma forma de efetivação dos direitos culturais e sociais.

\section{REFERÊNCIAS BIBLIOGRÁFICAS}

ARENHART, G. Gestão coletiva de direitos autorais e a necessidade de supervisão estatal. Curitiba, 2011. Disponível em: <www.gedai.com.br/sites/default/files/arquivos/gestao_coletivasupervisao_estatal.pdf> Acesso em: 22 set. 2016

ASCENSÃO, J. de O.; Santos, M. J. P.; Jabur, W. P. Direito Autoral. Série GVLaw. Coord: Manoel J. Pereira dos Santos e Wilson Pinheiro Jabur. Editora Saraiva, 2014. São Paulo - SP.

BARLOW, J. P. The Economy of Ideas. 1994. Disponível em: <http://archive.wired.com/wired/archive/2.03/economy.ideas_pr.html> Acesso em: 21 ago. 2017.

BOND, T. "How Artificial Intelligence is set to disrup our legal framework for Intellectual property Rights”, 2017. Disponível em <http://www.ipwatchdog.com/2017/06/18/artificial-intelligencedisrupt-legal-framework-intellectual-property-rights/id=84319/>. Acesso em 26 set. 2017.

BRANCO, S. A Lei Autoral Brasileira Como Elemento de Restrição à Eficácia do Direito Humano à Educação. Sur - Revista Internacional de Direitos Humanos, Número 6. Ano 4/2007. Disponível em: < http://www.scielo.br/pdf/sur/v4n6/a07v4n6.pdf > Acesso em: 21 ago. 2017.

BRASIL. Constituição da República Federativa do Brasil (1988). Promulgada em 05 de outubro de 1988. Disponível em: <http://www.planalto.gov.br/ccivil_03/Constituicao/Constituicao.htm.> Acesso em: 21 ago. 2017.

Lei $n^{\circ} .5 .988$, de 14 de dezembro de 1973, Lei que regulava os direitos autorais, revogada 
pela lei $\mathrm{n}^{\text {o }}$ 9.610, de 19 de fevereiro de 1998. Disponível em: <http://www.planalto.gov.br/ccivil_03/leis/L5988.htm.> Acesso em 1 out. 2017.

Lei $\mathrm{n}^{\circ}$ 9.610, de 19 de fevereiro de 1998. Altera, atualiza e consolida a legislação sobre direitos autorais e dá outras providências. Disponível em: <http://www.planalto.gov.br/ccivil_03/leis/L9610.htm> Acesso em: 02 de fev. 2017. Acesso em: 27 ago. 2017.

Lei $n^{\circ}$ 10.406, de 10 de janeiro de 2002. Novo Código Civil Brasileiro. Disponível em: < http://www.planalto.gov.br/ccivil_03/Constituicao/Constituicao.htm. > Acesso em: 27 ago. 2017.

. Lei $\mathrm{n}^{\circ} 12.853$, de 14 de agosto de 2013, altera os arts. 5 $, 68,97,98,99$ e 100, acrescenta arts. 98-A, 98-B, 98-C, 99-A, 99-B, 100-A, 100-B e 109-A e revoga o art. 94 da Lei n ${ }^{\circ} 9.610$, de 19 de fevereiro de 1998, para dispor sobre a gestão coletiva de direitos autorais, e dá outras providências. Disponível em: < http://www.planalto.gov.br/CCIVIL_03/_Ato20112014/2013/Lei/L12853.htm.> Acesso em: 25 ago. 2017.

Convenção para a Salvaguarda do Patrimônio Cultural Imaterial. Paris, 17 de outubro de 2003. Inserido no ordenamento jurídico brasileiro por meio da promulgação do Decreto no. 5.753, de 12 de abril de 2006. Disponível em: <http://www.planalto.gov.br/ccivil_03/_ato20042006/2006/decreto/d5753.htm.> Acesso em: 23 set. de 2017.

Decreto no 678, de 6 de novembro de 1992. Promulga a Convenção Americana sobre Direitos Humanos (Pacto de São José da Costa Rica), de 22 de novembro de 1969. Disponível em: <http://www.planalto.gov.br/ccivil_03/decreto/d0678.htm.> Acesso em 05 de out. 2017.

Decreto no. 5.753, de 12 de abril de 2006. Promulga a Convenção para a Salvaguarda do Patrimônio Cultural Imaterial. Paris, 17 de outubro de 2003. Disponível em: <http://www.planalto.gov.br/ccivil_03/_ato2004-2006/2006/decreto/d5753.htm.> Acesso em 10 ago.2017. 
DIAS, J. C. V., SANTANNA, L. e SANTOS, B. The Legal Treatment of Know-How in Brazil: Peculiarities and Controversies of a New Intangible Form. Quaestio Iuris. vol. 09, $n^{\circ}$. 04, Rio de Janeiro, 2016. pp. 2312 -2334.

IRATI, A. Autoria e Cultura na pós-modernidade. In: Ci. Inf., Brasília, v. 27, n.2, p. 189-192, maio/agosto, 1998. Disponível em:<http://www.scielo.br/pdf/ci/v27n2/irati.pdf>Acesso em 25 ago. 2017.

KAUARK, G. Os Direitos Culturais e seu lugar no plano nacional de cultura do Brasil. IV Seminário Internacional de Políticas Culturais da Fundação Casa Rui Barbosa. Setor de Políticas Culturais. Rio de Janeiro, 2013. Disponível em: <culturadigital.br/politicaculturalcasaderuibarbosa/files/2013/11/Giuliana-Kauark.pdf> Acesso em: 20 de ago. 2017.

PEREIRA, C. M. S. “Instituições de Direito Civil. Vol. IV. Direitos Reais. Ed. Forense. 2004.

PRETTO, N. D. L.; CORDEIRO, S. N.; OLIVEIRA, W. S. Produção cultural e compartilhamento de saberes em rede: entraves e possibilidades para a cultura e a educação. Educ. rev., Belo Horizonte , v. 29, n. 3, p. 17-40, Setembro, 2013. Disponível em: $<$ http://www.scielo.br/scielo.php?script=sci_arttext\&pid=S0102$46982013000300002 \& \operatorname{lng}=\mathrm{en} \& n r m=$ iso>. Acesso em: 27 ago. 2017.

REMOALDO, P. Copyright Infringement, Law and Borders on the Internet. Portugal. 1998. Disponível em: <https://web.fe.up.pt/ mgi97018/is/copyright.html> Acesso em: 15 ago. 2017.

SCHREIBER, A. Função Social da Propriedade na Prática Jurisprudencial Brasileira. Disponível em: $\quad$ <http://xa.yimg.com/kq/groups/24009970/1533308165/name/Schreiber\%2520\%2520Propriedade.pdf >. Acesso em 03 out. 2017.

SOUZA, A. R. Direitos Culturais no Brasil. Editora Azougue, Rio de Janeiro, 2012. 
UNESCO. Acesso à Cultura no Brasil. Disponível em: <http://www.unesco.org/new/pt/brasilia/culture/culture-and-development/access-to-culture/> Acesso em: 19 out. 2017.

- Convenção sobre a proteção e promoção da Diversidade das Expressões Culturais. 2005. Disponível em: <http://www.ibermuseus.org/wp-content/uploads/2014/07/convencao-sobrea-diversidade-das-expressoes-culturais-unesco-2005.pdf> Acesso em: 10 de out. 2017.

Declaração Universal dos Direitos Humanos. Adotada e proclamada pela resolução 217 A (III) da Assembléia Geral das Nações Unidas em 10 de dezembro de 1948. Disponível em: <http://unesdoc.unesco.org/images/0013/001394/139423por.pdf.> Acesso em 05 out. 2017.

WACHOWICZ, M. A Revisão da Lei Autoral Principais Alterações: Debates e Motivações. PIDCC, Aracaju, Ano IV, Edição $n^{\circ}$ 08/2015. Fevereiro de 2015. Disponível em: <http://pidcc.com.br/artigos/082015/21082015.pdf> Acesso em: 6 ago. 2017.

Informações oficiais do site da Creative Commons Organization. Disponível em: <http://www.creativecommons.org>. Acesso em: 02 ago. 2017. 